University of Nebraska - Lincoln

DigitalCommons@University of Nebraska - Lincoln

USDA Forest Service / UNL Faculty Publications U.S. Department of Agriculture: Forest Service -National Agroforestry Center

2012

Towards a life-history-based management framework for the effects of flow on juvenile salmonids in streams and rivers

\author{
K. H. Nislow \\ USDA Northern Research Station, knislow@fs.fed.us \\ J. D. Armstrong \\ Marine Scotland Science, John.Armstrong@scotland.gsi.gov.uk
}

Follow this and additional works at: https://digitalcommons.unl.edu/usdafsfacpub

Nislow, K. H. and Armstrong, J. D., "Towards a life-history-based management framework for the effects of flow on juvenile salmonids in streams and rivers" (2012). USDA Forest Service / UNL Faculty Publications. 228.

https://digitalcommons.unl.edu/usdafsfacpub/228

This Article is brought to you for free and open access by the U.S. Department of Agriculture: Forest Service -National Agroforestry Center at DigitalCommons@University of Nebraska - Lincoln. It has been accepted for inclusion in USDA Forest Service / UNL Faculty Publications by an authorized administrator of DigitalCommons@University of Nebraska - Lincoln. 


\title{
Towards a life-history-based management framework for the effects of flow on juvenile salmonids in streams and rivers
}

\author{
K. H. NISLOW \\ USDA Forest Service Northern Research Station, University of Massachusetts, Amherst, MA, USA
}

\author{
J. D. ARMSTRONG \\ Marine Scotland Science, Faskally, Pitlochry, Perthshire, UK
}

\begin{abstract}
Salmonid fishes have complex life cycles involving major changes in habitat requirements at different stages in their life history. Effects of changes in flow and flow regime on salmonids are therefore highly stagespecific. Successful management requires consideration of stage-specific influences and integration of these effects over the entire life history to predict ultimate impacts on abundance and population viability. The state of science regarding stage-specific influences of flow regime on juvenile salmonids and their habitats, referring specifically to fundamental attributes of natural regimes and to characteristic alterations of these regimes associated with water management, is reviewed. It appears that a key consideration in integrating the stage-specific impacts of flow is the extent to which flow-related losses or gains early in ontogeny can be compensated by increased growth or survival later in juvenile life history. Further, fundamental interactions between flow and water temperature must be incorporated into the robust models ultimately required for science-based management. In the absence of such models and data, the current state of science may be sufficient to target specific aspects of flow regimes that are critical to multiple life-history stages, which can then serve as a basis for interim flow prescriptions and subsequent adaptive management.
\end{abstract}

KEYWORDS: dams, Europe, flow regulation, North America, Salmo salar, Salmo trutta.

\section{Introduction}

Managing river flows for multiple uses in the North Atlantic region must recognise the importance of flow regimes for salmonid fishes. The nature of flowing water is an essential component of the environment of stream and river fishes across multiple spatial and temporal scales. At the finest scales, flow variation determines energy intake and swimming costs for individual fish as salmonids depend on flow to deliver prey and must swim against the current to hold their position (Fausch 1984) or disperse to new habitats (McCormick et al. 1998). At the largest scales, flow regimes, interacting with underlying geology and land use, shape the physical dimensions of rivers and streams and determine the availability of suitable physical habitat (Poff et al. 1997). Superimposed on these multiple scales of influence are interactions between flow and other critical determinants of salmonid performance, including physical factors such as temperature and water chemistry, and biotic factors such as predators and competitors. In spite of these complexities, an existing body of research has attempted to link characteristics of flow regimes with survival, growth and dispersal of juvenile salmonids (Bradford \& Heinonen 2008; Murchie et al. 2008). Scientific information on the relationship between flow and salmonids derives from studies using a wide range of approaches [reviewed by Armstrong and Nislow (2012)]. These include: long-term population studies that also monitor flow regimes; studies of flow and habitat use and preference; process-based approaches that examine the mechanisms relating flow directly to growth, survival and fitness; and experimental flow 
manipulations in the field (often in the context of river management actions).

For salmonid fishes, the life cycle is the essential template on which to consider the effects of stream flow. Salmonids begin their independent life in the stream as small $(<2 \mathrm{~cm}$ long, weighing $<0.25 \mathrm{mg})$ vulnerable fry. After their first spring and summer, those fish that make it past the fry stage have increased in mass as much as an order of magnitude and are considered parr (or in the case of stream-resident populations, overyearling juveniles). They spend one to several years in this stage, during which they experience substantial seasonal and among-year variation in flow regimes, and may increase in size an additional order of magnitude. For anadromous species such as Atlantic salmon, Salmo salar L., parr become smolts as they outmigrate and undergo the behavioural and physiological changes that prepare them for life in sea water. In this review, effects of flow and flow regime on each of these broadly defined stages are considered, and a framework for incorporating these relationships in predicting ultimate effects on abundance and production is outlined.

\section{Stage-specific effects of flow on salmonids}

\section{Flow and the fry stage}

Despite major differences in spawning and incubation times across species and geographic areas, salmonids in the north temperate zone almost universally emerge as fry from gravel nests within the substrate during the spring season (between March and June). As a consequence, they experience a highly dynamic and variable flow environment in the period after emergence, as winter evapo-transpiration and precipitation regimes yield to spring conditions, during a time when they are undergoing a major transition from life within the gravel and dependence on maternal yolk reserves to independent feeding and territorial behaviour (Armstrong \& Nislow 2006).

An important consideration for the fry stage is that suitable territories for feeding may be in limited supply because only a narrow range of microhabitats appear to yield favourable foraging conditions (Nislow et al. 2000; Armstrong \& Nislow 2006). Suitable territories are also potentially limited by the presence of larger older fish, which may exclude fry from the habitats that these larger fish prefer. Both of these limitations may be particularly acute in large rivers, where only the area near banks and river margins may be suitable for fry (McKinney et al. 2001). Competition for this limited number of suitable territories is intense, as thousands of individuals emerge from gravel nests, and in some situations, a large majority of fry fail to locate suitable territories and succumb to starvation (Kennedy et al. 2008). Fry are also highly vulnerable to predators during emergence (Leániz et al. 2000; Henderson \& Letcher 2003). As a result, mortality is generally very high at this life stage.

Flow exerts a primary influence on fry habitat and fitness. High flows can result in microhabitat velocities that exceed the limited swimming capacities of small post-emergent fry (Tetzlaff et al. 2005) and can cause catastrophic displacement. Increased drift of brown trout, Salmo trutta L., fry in response to high flows was observed in a semi-natural stream channel in the French Alps (Liebig et al. 1998). Even at lower flow levels, and particularly in streams that lack habitat heterogeneity, high flows after emergence can result in microhabitat velocities that are too rapid for effective foraging (Nislow et al. 2000) or may cause excessive energetic costs for holding station in the current (Kemp et al. 2006; Armstrong 2010). In some systems however, the opposite situation may hold, when flows may be too low to provide a sufficient flux of drifting invertebrate prey (Fausch 1984), or by reducing total habitat area, may increase intraspecific competition (Nislow et al. 2004).

Reflecting these influences, studies suggest that the emergence and post-emergence periods are closely tuned to flow regimes. In Norwegian rivers, brown trout and salmon typically emerge either before or after the largest floods of the year (Jensen et al. 1991), and in years where floods coincided with peak emergence, high mortality was the result (Jensen \& Johnsen 1999). Year-class failures of age- 0 salmonids associated with flood events have also been observed by Letcher \& Terrrick (1998) and Nislow et al. (2002). Other studies indicated that high mortality can also result when fry emerge (or are stocked) when flows are either too high (Letcher et al. 2004) or too low (Solomon \& Paterson 1980; Lobon-Cervia 2004). Following the post-emergent period, flow effects appear to be manifest more in terms of fry growth rates than in terms of survival (Einum et al. 2006), with low summer flows during dry summers associated with low rates of growth (Nislow et al. 2004).

These relationships suggest that hydrological alteration during the fry stage can have important impacts on survival and growth. Perhaps most dramatically, hydropeaking flows can cause the nearshore sheltered habitats that fry require to change dramatically in flow and depth over the course of hours or days. Turning these critical fry habitats into varial zones (Korman \& Campana 2009) that are dewatered for all or most of 
the day negatively impacts fry growth and survival. Direct stranding of age- 0 salmonids can be an important effect in some situations. Hvidsten (1985) recorded substantial stranding of age-0 Atlantic salmon, Salmo salar $\mathrm{L}$. and brown trout in a Norwegian river. In a laboratory stream, experimental dewatering caused stranding of a substantial proportion of age- 0 brown trout (up to $22 \%$ ) with effects being exacerbated by rapid rampdown rates, cold temperatures and under daytime vs nighttime conditions (Halleraker et al. 2003). Loss of bank and stream margin habitat under short-term flow reductions may also increase vulnerability to predators, which was suggested to underlie the higher mortality experienced by age- 0 Atlantic salmon, brown trout and European grayling, Thymallus thymallus (L.), in a highly regulated chalk stream in southern England (although not in a hydropeaking management regime) (Riley et al. 2009). In the Colorado River in south-western USA, Korman and Campana (2009) found that hydropeaking caused rainbow trout, Onchorynchus mykiss (Walbaum) fry to avoid shoreline habitats that they normally prefer. In addition, growth rates (as measured by otolith increments) were greater on days when flows were steady than on days when hydropeaking flows occurred. Concordant with these observations, restoration of stable flows in this system greatly improved fry growth and survival (McKinney et al. 2001). Using PHABSIM modelling, Gibbins et al. (2001) suggested that pulsed flows in the North Tyne system in northeast England would have similar negative effects on Atlantic salmon fry, and that flow restoration would ameliorate these impacts, but this prediction was not tested. Finally, exposure of nearshore habitats in varial zones because of hydropeaking can lower the abundance of benthic invertebrates, which are an important prey base for salmonids in large rivers (Troelstrup \& Hergenrader 1990; Blinn et al. 1995). As salmonid production in north temperate streams may be food limited (Nislow \& Lowe 2006; Ward et al. 2009), reduction in prey availability may represent an added negative effect.

These results suggest that dam storage and diversion during the post-emergent period, if they favour low but stable flows during the post-emergent period, may actually increase fry survival rates, but this has only been directly tested in the Colorado River. By contrast, in the Columbia River system, water withdrawals, even in the absence of rapid rampdowns, decreased the amount of shallow water habitat required by Chinook salmon, Onchorhynchus tshawytscha (Walbaum), fry (Kukulka \& Jay 2003). In addition, in large rivers where floodplain and side-channel rearing habitats are important resources, reduction of high spring flows can disconnect rivers from their floodplains and reduced the availability and quality of these habitats (Sommer et al. 2004). Timing of storage and release is also likely to be critical, as sudden releases from storage facilities can cause unnatural levels of bed movement and sediment disturbance with negative effects on fry if these occur during or immediately after emergence or stocking. Further, water storage and abstraction can exacerbate low flows, particularly during dry summer periods with negative impacts on fry growth rates (Nislow et al. 2004; Davidson et al. 2010), but again direct tests with experimental flows are lacking.

\section{Flow and the parr stage}

For those individuals that survive the fry stage and become parr (or stream-resident juveniles), increased size and swimming ability allows greater ability to determine their own energetic status and habitat use. As a consequence, unlike vulnerable fry, parr are much less likely to experience direct mortality from extreme flow events (Lobon-Cervia 1996; Letcher \& Terrick 1998; Nislow et al. 2002). The effects of flow on parr are correspondingly more subtle and complex.

Owing to the long duration of this life-history stage, parr must deal with substantial among-season and among-year variation in flow regimes. Changes in the magnitude, variability and timing of flows mean very different things in different seasons. For example, high flows in the spring, when invertebrate prey is abundant, may increase growth rates by increasing prey encounter rates for drift-feeding salmonids (Nislow et al. 2000; Hayes et al. 2007). By contrast, high flows during the winter can increase swimming metabolic costs at a time when prey is scarce, causing individuals to use up metabolic reserves (Huusko et al. 2007). These considerations argue for season-specific as well as stage-specific considerations.

Another important attribute of the parr stage is that having made it past the gauntlet of high fry mortality, individuals tend to be more risk-averse. In laboratory studies, they are reluctant to abandon their territories, even when flow conditions within these territories deteriorate (Stradmeyer et al. 2003). They spend less time actively holding station and foraging than do fry, and more time in sheltered locations (Armstrong et al. 2003). Further, parr tend to respond to increases in prey availability not by increasing their consumption rates, but by decreasing the amount of time, they spend actively feeding and increasing the time they spend in shelters (Orpwood et al. 2006). The importance of shelters has been demonstrated by significant relationships 
between shelter availability and parr growth and survival in both laboratory and field studies (Finstad et al. 2007).

The role of shelters and sheltering behaviour are important considerations with respect to the influence of flow regime on parr growth and survival. At the finest scale, this may be why microhabitats used by parr are characterised by a wide range of local velocities, in contrast to the more narrowly defined velocity ranges considered to be suitable for fry (Armstrong et al. 2003). At the largest scale, these considerations suggest that flow regime may have its strongest influence via effects on streambed composition-associated changes in shelter availability. For example, bed-mobilising flows (which in many systems correspond to the 2-year recurrence interval or bankful flood event) may be critical in preventing embeddedness and armouring of the streambed and allowing for the provision of interstitial spaces that Atlantic salmon and other species use as shelters (Salant et al. 2007).

While salmonids in the parr stage are often quite resistant to floods, which may actually have a beneficial effect on habitat, there is some evidence that winter floods can have measurable negative effects at this stage. Particularly in cold northern rivers where ice formation and movement is a frequent occurrence, winter floods can cause catastrophic scouring of river beds and high stream current speeds at low temperatures where fish swimming performance is lower than during warmer seasons. Cunjak and Therrien (1998), in a long-term study of Atlantic salmon recruitment in the eastern Canada, found that population abundance was negatively correlated to the magnitude of winter flooding, largely driven by low recruitment during a year with catastrophic ice movement. In the same system, Arndt et al. (2002) found that extreme summer floods may be associated with low growth rates of age0 and overyearling salmon, but these effects were minor and of relatively short duration.

Below the magnitude of bed-mobilising flows, annual variation in stream flow has been observed to have effects on parr and stream-resident over-yearling salmonids. In a long-term study in western Massachusetts, north-eastern USA, the effects of season-specific variation in flow regimes on growth, survival and movement rates of individually marked brook trout, Salvelinus fontinalis (Mitchill), and Atlantic salmon were examined using empirical models (Davidson et al. 2010; Xu et al. 2010a,b). Flow regime had little influence on the survival rates of salmon parr in any season. Reduced summer flows negatively affected survival of brook trout, but this was only true in small tributaries for fish in the largest size class. By contrast, flow regime had a major influence on growth rates of both species. This result is concordant with results of studies at the fry stage, which suggest that negative effects of biotic and abiotic factors are manifest in terms of survival earlier in ontogeny, and in growth and movement later in juvenile life history. For salmon, the effects of variation in flow on growth rates substantially outweighed the effects of other physical (water temperature) and biotic (intra and interspecific population density) factors. For both species, increased flow magnitude was generally associated with higher growth rates, resulting in $24-50 \%$ decreases in the size at age of juvenile salmon and trout under low-flow conditions. However, effects of flow were season-specific, as growth increased with stream flow during the spring, summer and autumn, but decreasing with flow during winter (Fig. 1). Concordant with these results, but in a very different system, adult abundance of summer-run steelhead (anadromous Onchorhynchus mykiss) was positively correlated with flow conditions experienced during the parr stage in summer, but the study was of insufficient detail to determine whether these effects were the result of increased survival, increased growth or some combination of the two (Smith 2000).

These influences at the parr stage suggest that flow regulation and alteration will have important implications at this life-history stage, and abstraction during the time when salmonids generally achieve most of their growth (spring through fall) will have negative effects on growth and size. Given the strong influence of growth and size on generation time and fecundity, these effects have the potential to reduce greatly productivity and population growth rates. Concordant with this view, Baran et al. (1995) found that biomass and density of brown trout were consistently reduced below watersupply dams in French Pyrenees streams with the magnitude of reduction generally proportional to the decrease in wetted area. However, because flow reductions may affect both growth and survival in some situations, estimates of these effects require models that integrate both of these population vital rates.

Effects of hydropeaking and rapid diel fluctuations are less clear for parr than for fry. In relatively smallscale laboratory studies, salmon tend to redistribute readily to pools during rapid dewatering, even in the presence of competing brown trout (Huntingford et al. 1999; Stradmeyer et al. 2008). Halleraker et al. (2003) found that brown trout parr in an artificial stream were rarely stranded, even under the same drawdown conditions that resulted in the stranding of a substantial portion of age- 0 fry. By contrast, in a more natural small stream, many salmon parr remained on 


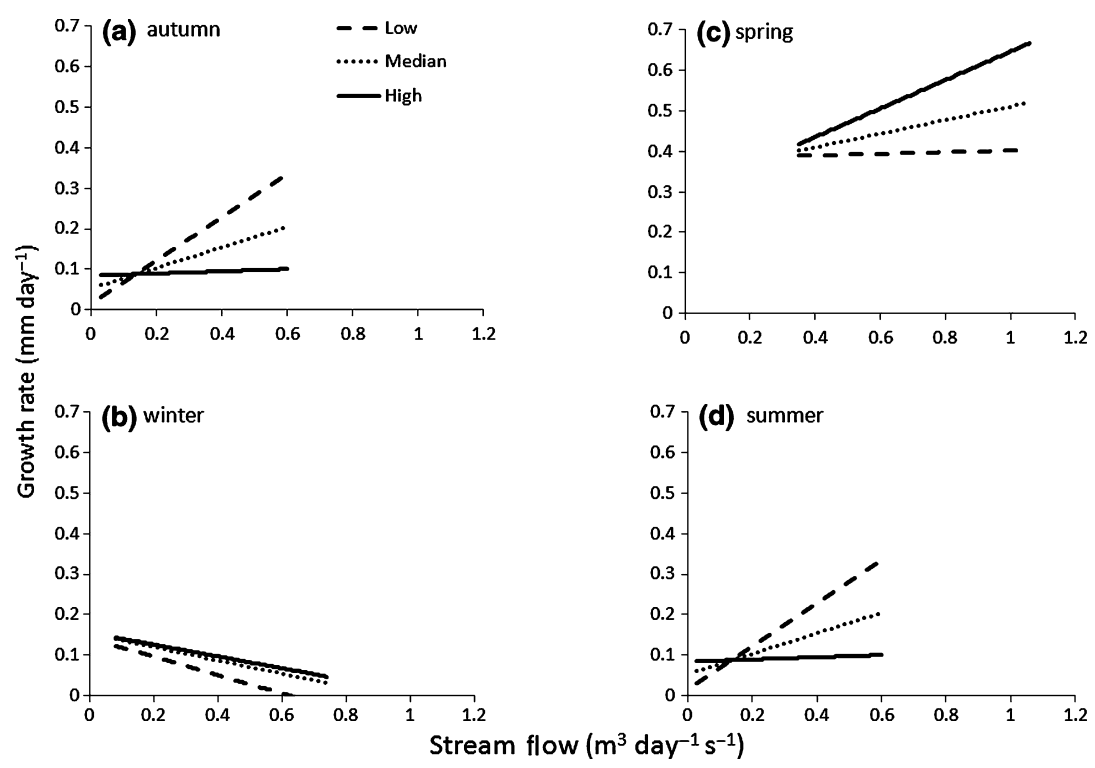

Figure 1. The relationship between brook trout parr growth rate $\left(\mathrm{mm}\right.$ total length day $\left.{ }^{-1}\right)$ and stream flow $\left(\mathrm{m}^{3} \mathrm{~s}^{-1}\right.$ day $\left.^{-1}\right)$ over 6 years of a long-term study in West Brook, MA, USA. Stream flow is the average daily flow for a seasonal time interval; data and details of methods from Xu et al. (2010a).

riffle habitats during dewatering (Armstrong et al. 1998). Fish that moved to pools tended to be those that had previously explored the range of habitats available even though they then adopted home ranges on riffles. Larger-scale experiments in wide rivers have found higher mobility among free ranging salmon parr (Berland et al. 2004), such that no stranding occurred during hydropeaking. Older juvenile and adult brown trout in a western Canadian river moved into sheltered areas (interstitial spaces in the streambed and large wood accumulations in pools) during pulsed flows from a large reservoir (Bunt et al. 1999). In the Shoshone River in the western USA, brown trout and cutthroat trout, Onchorhynchus clarki (Richardson), were observed to seek shelter in response to low flows (Dare \& Hubert 2002). These directed movements demonstrated that older larger fish can behaviourally avoid direct impacts, although these movements and associated sheltering behaviour may incur time and energy costs. However, such results must be interpreted with caution because there would likely have been strong selection prior to the experiments against those individuals whose innate behaviours made them vulnerable to stranding. Hence, populations exposed to hydropeaking may be biased towards mobile individuals, with possible consequences for overall production. Irvine et al. (2009) determined that the degree of stranding in juvenile stream fish tends to increase with local population density, period of wetted history and ramping rate and is reduced by an initial conditioning reduction.
Other mechanisms apart from direct stranding are likely to affect the growth and survival of parr. Potential effects of reduced food availability resulting from hydropeaking previously pointed out for fry would also affect parr. High volume storage and flood mitigation may be a particular problem at the parr stage via effects on habitat. When flow regulation is large enough to prevent the occurrence of bed-mobilising flows, streambeds can become armoured because of increasing embeddedness and substrate packing (Salant et al. 2007). These effects will in turn reduce the availability of interstitial shelter space, which has been shown to be critical for Atlantic salmon parr growth and survival (Finstad et al. 2007).

\section{Flow and the smolt stage}

While the timing and duration of the smolt stage varies across salmonid species, it is generally of short duration compared with the parr stage, particularly for Atlantic-basin species such as Atlantic salmon and sea trout, who rear at least 1 year in fresh water (usually longer) then rapidly outmigrate to the ocean after smolting. The defining characteristics of this stage therefore relate to large-scale migration and the associated changes involving the transition between life in fresh and sea water. For sea trout and Atlantic salmon, mortality during this stage can strongly influence population dynamics and production, because there is little evidence of density-dependent compensation later in life history (Jonsson et al. 1998). 
Further, because smolts may begin their migration in the headwaters and must navigate through mainstem rivers, they are subject to the full range of environmental alterations with river systems.

Like fry emergence, smolt migration appears to be highly tuned to characteristics of natural flow regimes. Generally, most smolts outmigrate during the descending limb of the spring hydrograph (McCormick et al. 1998), and flow is a cotrigger along with temperature and day length initiating migration (McCormick et al. 1998; Hembre et al. 2001). Flows must be of sufficient magnitude to aid downstream migration (which to some extent is a passive process), and there is evidence that speed of migration is dependent on flow regime (McCormick et al. 1998) with higher flows leading to more rapid downstream migration. Migration speed appears to be a critical determinant of successful migration for smolts. Examples from both Pacific (Cada et al. 1997; Budy et al. 2002) and Atlantic-basin species (McCormick et al. 1998) have demonstrated that low flows during smolt migration are associated with low smolt and adult survival. This is likely due to several mechanisms. Delays may increase vulnerability to within-river predators such as esocids and centrarchids (Rieman et al. 1991). Migratory delays may also cause smolts to lose the physiological and behavioural characteristics that prepare them for life in seawater, as retention of these characteristics has been shown to be time- and temperature-dependent (McCormick et al. 1999).

Flow alteration has a profound influence on smolts. Barriers to passage, particularly large dams on mainstem rivers, cause substantial smolt mortality (McCormick et al. 1998). While smolt mortality at dams has multiple causes, flow alteration exerts a pervasive influence. Water storage and abstraction during the smolt run slows downstream passage (Budy et al. 2002). Even without large storage and abstraction capacity, the creation of backwater pools with negligible flow velocities will slow migration and attract predators. The influence of flow on outmigrating smolts has been perhaps best studied in the highly altered Columbia River system in the western United States. For autumn-run Chinook salmon stocks, summer flow augmentation increased smolt survival through the hydrosystem (Connor et al. 2003). At a more site-specific scale, variation in the lateral and longitudinal patterns of river flow has a strong influence on the ability of smolts to pass through potential barriers and passage structures. The science and engineering involved constitutes an entire field unto itself, with increasing calls for more explicit incorporation of fish behaviour in design and imple- mentation of these structures (Katopodis 2005; Johnson \& Dauble 2006; Enders et al. 2009a,b).

\section{Stage-specific interactions with other habitat factors}

Flow interacts with a wide range of abiotic and biotic variables in determining salmonid performance. One of these factors, water temperature, may be particularly important to consider. Flow and water temperature are major determinants of energetics and metabolism of stream fishes with consequent strong influences on growth, survival and fitness. In addition, both temperature and flow regimes are predicted to be altered under global climate change scenarios with implications for salmonid rivers (Jonsson \& Jonsson 2009). Increasing concerns about managing water resources under future change and uncertainty makes understanding this interaction all the more important.

For fry, interactive effects of temperature and flow can have several different effects. Emergence time in salmonids is a direct function of water temperature during incubation (Crisp 1988). Increased winter temperature is one of the most robust predictions of current GCM models for north-eastern North America and northwest Europe (Walsh \& Kilsby 2007) and will result in earlier emergence of salmonid fry. Depending on concurrent changes in flow regime and flow management, this early emergence may cause a mismatch between habitat requirements and flow conditions at emergence, with negative impacts on survival (Letcher et al. 2004). For both fry and parr, models suggest that low flows will exacerbate the negative effects of increased temperatures on growth during summer and autumn (Nislow et al. 2004; Davidson et al. 2010; Xu et al. 2010a) (Fig. 1). During the spring season in West Brook, as well as in many other north temperature sites, increased temperatures have been predicted to increase growth rates, potentially ameliorating negative effects in other seasons. However, the positive effect of increased temperature was strongly dependent on the availability of sufficient flows in spring (Fig. 1). Finally, for smolts, increased spring temperatures will narrow the smolt window, making it even more important that spring flows are of sufficient magnitude for rapid migration (McCormick et al. 1999).

More complex interactions between temperature, flow and other factors are likely to have important influence, but are poorly studied. While a few studies have indicated that the effects of competitors (De Staso \& Rahel 1994) and predators (Reese \& Harvey 2002) may be strongly dependent on temperature, 
similar studies on flow-dependent competition and predation are largely lacking. In a series of laboratory studies, Greenberg (1999) found that habitat use of brown trout and European grayling was affected by the interaction between predator presence and flow level, but did not observe any measurable effects on performance measures (growth, survival or movement). A laboratory study by Becker et al. (2003) found that vulnerability of rainbow trout to a gill parasite was markedly greater under both decreased flow and increased temperature conditions. Studies that include variation in flow in the context of multiple stressors will both reveal potential mechanisms and give a perspective on the importance of changes in flow regime in environments changing in multiple dimensions.

\section{Integrating effects of flow across life-history stages}

While effects of flow can be highly stage-specific, integrating across stages is key to determining ultimate influences on production and population size. In essence, effects on population size and freshwater production are jointly determined by the magnitude of the stage-specific effect (reduction in stage-specific production or survival) and the compensatory scope of subsequent life-history stages (the ability of increased growth and survival to compensate for earlier losses).

In general, while losses via mortality are large, compensatory scope is high early in life history. For example, while altered flows may decrease incubation success (Tetzlaff et al. 2005; Malcolm et al., in press), evidence suggests that under some conditions, because of density-dependent early fry survival, different numbers of successfully incubated eggs will produce similar numbers of fry, cancelling out effects of flow at the egg stage (Einum \& Nislow 2005). This density dependence appears to play a large part in dampening the effects of decreasing number of spawners on Atlantic salmon smolt production in the long-term study of the Girnock Burn in northeast Scotland (Gurney et al. 2008). By contrast, losses at later stages may be lower on a proportional basis, but have a larger ultimate impact on population size, because of limited subsequent compensatory scope. For example, losses at the smolt stage are unlikely to be compensated for, as there is no evidence for density-dependent survival or growth while at sea (Jonsson et al. 1998).

Given these considerations, what does existing information say about the importance of stage-specific impacts on population size and production? Several studies have demonstrated that flow-associated early losses (fry stage) can be of sufficient magnitude to determine the size of cohorts. Low fry survival associated with low-flow years resulted in weak cohorts (Lobon-Cervia 2004) of stream-resident brown trout in Spain. Elimination of peaking flows and restoration of lateral habitats in the Colorado River enhanced fry survival and growth and resulted in substantial increases in population size (McKinney et al. 2001). By contrast, other studies suggest population limitation during later life-history stages (Jager et al. 1997; Crozier \& Zabel 2006). These differences indicate that population regulation occurs at different stages under different conditions, a suggestion that has been reinforced by the modelling of Einum et al. (2008).

Several groups have attempted to incorporate stagespecific flow regimes into multi-factor models of salmonid populations. However, the importance of flow to population dynamics appears to vary considerably among models and among locations. In a modelling study of Chinook salmon in a Pacific coastal US river, the most influential environmental factor during the juvenile phase was temperature, not flow (Jager et al. 1997). Further, optimal flow regimes differed greatly for differing management objectives (Jager \& Rose 2003). In the Columbia River basin, models indicated that autumn flow regimes experienced by sub-yearling juveniles were critical factors for some Chinook salmon stocks, but had little influence on the dynamics of other stocks (Crozier \& Zabel 2006).

\section{Conclusions}

A review of the state of science reveals complex, stagespecific effects of stream and river flow on salmonids. Despite this complexity, a general summary of observed and likely effects of flow modifications for juveniles, particularly relevant to north Atlantic-basin salmonids (Atlantic salmon, brown trout and brook trout), can be provided and placed in the context of current and predicted water availability and demand (Table 1). At this point, are there general recommendations to be made to the management and research community?

Several considerations are motivated by a lifehistory-based approach:

- For early life-history stages, determining whether flow-associated increases exceed carrying capacities for later stages may be more important that simply estimating the magnitude of effects. For later lifehistory stages, an emphasis on the role of flow on compensatory scope is critical. As an example, 


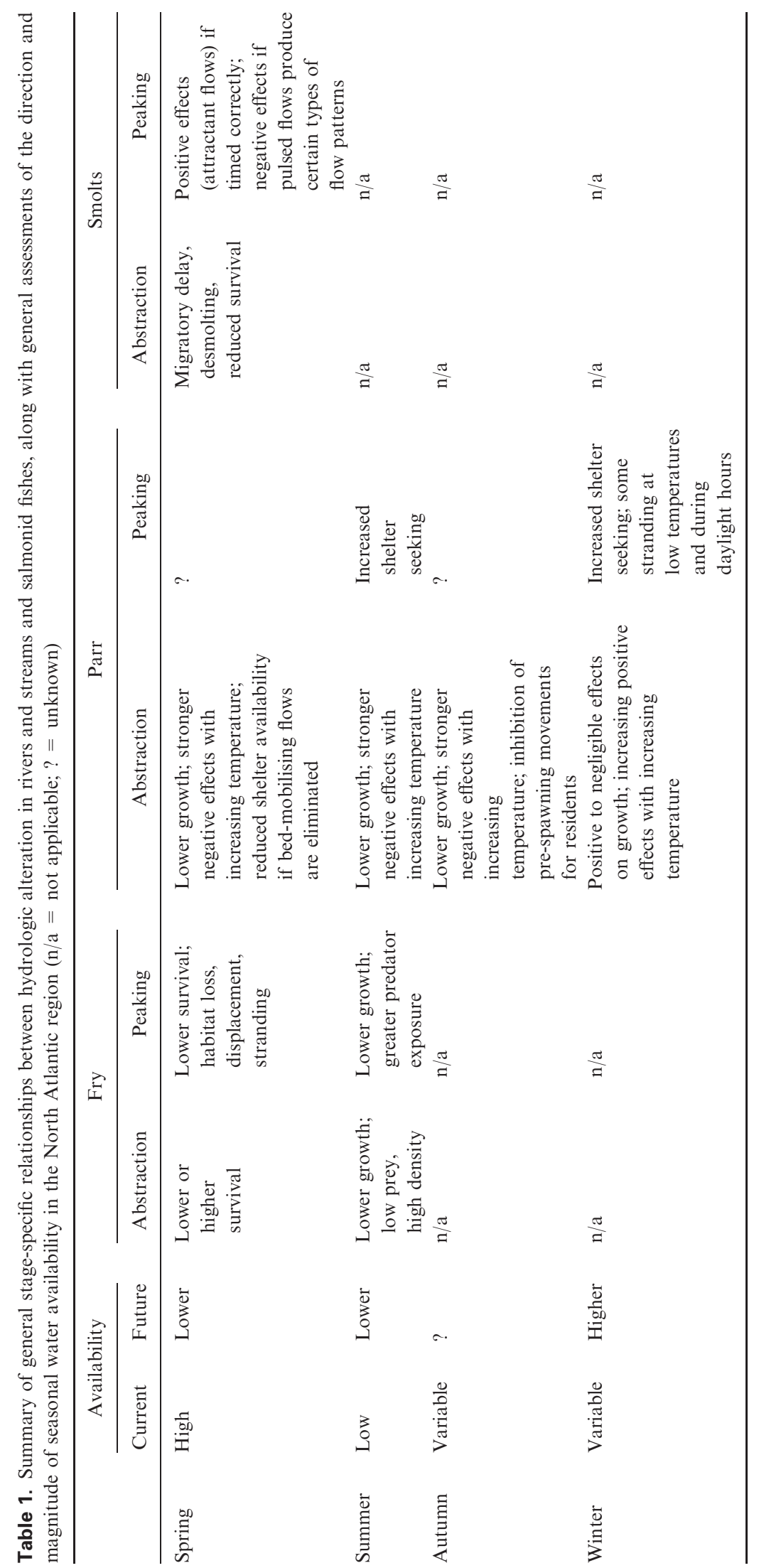


consider a population that has had poor fry recruitment in the previous year. Under normal or high flows, there may be substantial compensatory scope (via increased growth and fecundity and higher probability of maturation at low density). If these flows are reduced via abstraction, however, negative effects on growth will lead to lower size-dependent fecundity and maturation rates, strongly reducing the scope for compensation. Research and monitoring programmes can help identify these stage-specific bottlenecks and interactions.

- Flow affects both growth and survival. The interactions between these two aspects of fish performance jointly determine population dynamics. While effects on survival may appear to be more directly linked to population status, the strong size-dependence of population vital rates (such as maturation, migration and fecundity) can cause small differences in growth to have large impacts. Accounting for both these effects and the interactions requires the use of robust models and data (Armstrong \& Nislow, 2012).

- In many cases, sufficiently detailed information on population dynamics will be lacking. One strategy in these situations is to adopt a natural flow regime (Poff et al. 1997) approach, which shifts the focus away from detailed species requirements and more towards the extent to which key parts of the natural flow regime (for example those that have generally strong effects on multiple life-history stages) have or will be altered by flow management. Enders et al. (2009a,b) used this approach to establish guidelines for flow regulation in an eastern Canadian Atlantic salmon river.

As an example of how these guidelines might be applied, consider a comparison between the potential effects of flow alteration in the spring and winter season in a typical salmonid river (Table 1). Water availability is generally high during both these seasons, and river management schemes are often designed to capture this excess flow for human use, in some cases with the added benefit of preventing high flows from jeopardising lives and property via flooding. However, the biology of salmonid fishes at multiple life-history stages - fry survival, parr growth and shelter availability and smolt migration - is closely linked to spring flow regimes. This broad significance suggests that flow management that moves regimes closer to favourable conditions for multiple stages is essential. Further, because different flow prescription may have conflicting effects at different stages during this season (low flows may favour fry survival, but at the cost of smolt migration success) detailed consideration of the timing of flow schedules as well as detailed assessment of stage-specific population limitation. Again, in the absence of population data, a focus on moving flow management towards critical aspects of the natural flow regime, as opposed to tailoring flows for specific life stages, may help to avoid these conflicts. Finally, while spring is currently a season of generally high flow availability, GCM predictions indicated that spring flows are likely to decrease (Arnell 1999; Marshall \& Randhir 2008), putting more pressure on both fish populations and human use.

By contrast, in the winter season, it appears that some types of flow management would have much less negative impact or in some cases even positive impacts on juvenile life-history stages (Table 1). Also, in contrast to spring predictions, current GCM scenarios predict increases in winter precipitation and stream flow in the north Atlantic, reducing the likelihood of conflicts between fish and human needs during this season. While a recommendation to shift flow use to winter vs spring may be generally supported by the state of science, uncertainties in our understanding of salmonid winter ecology do present some risk (Huusko et al. 2007). These risks make it crucially important that such 'do the least harm' recommendations be used on a provisional basis and would ideally initiate an adaptive management process (Souchon et al. 2008). In such a scenario, the effects of these provisional recommendations would be monitored and tested, thereby providing critical data to inform both science and water management.

\section{Acknowledgments}

This paper was part of a conference and a workshop organised by the Atlantic Salmon Trust and its scientific panel. We are grateful to the organisers for the invitation to review this area of research, and to contributors to the conference and workshop for steering our attention to the areas of particular contemporary importance in management of water in UK. J. Coombs, C. Xu and B.H. Letcher provided helpful comments to the manuscript. The senior author would like to acknowledge the USDA Forest Service Northern Research Station and The Nature Conservancy for their ongoing support of research on flow and aquatic ecosystems.

\section{References}

Armstrong J.D. (2010) Variation in habitat quality for driftfeeding Atlantic salmon and brown trout in relation to water velocity and river discharge. In: P. Kemp (ed.) Proceedings of the Special Symposium of the Atlantic 
Salmon Trust: Salmonid Habitat Management and Restoration. Oxford: Wiley, pp. 1-12.

Armstrong J.D. \& Nislow K.H. (2006) Critical habitat during the transition from maternal provisioning in freshwater fish, with emphasis on Atlantic salmon (Salmo salar) and brown trout (Salmo trutta). Journal of Zoology 269, 403 413.

Armstrong J.D. \& Nislow K.H. (2012) Modelling approaches for relating effects of changes in river flow to populations of Atlantic salmon and brown trout. Fisheries Management and Ecology 19, 527-536.

Armstrong J.D., Braithwaite V.A. \& Fox M. (1998) The response of wild Atlantic salmon parr to acute reductions in water flow. Journal of Animal Ecology 67, 292-297.

Armstrong J.D., Kemp P.S., Kennedy G.J.A., Ladle M. \& Milner N.J. (2003) Habitat requirements of Atlantic salmon and brown trout in rivers and streams. Fisheries Research 62, 143-170.

Arndt S.K.A., Cunjak R.A. \& Benfey T.J. (2002) Effect of summer floods and spatial and temporal scale on growth and feeding of juvenile Atlantic salmon in two New Brunswick streams. Transactions of the American Fisheries Society 131, 607-622.

Arnell N.W. (1999) The effect of climate change on hydrological regimes in Europe: a continental perspective. Global Environmental Change 9, 5-23.

Baran P., Delacoste M., Dauba F., Lascaux J.M., Belaud A. \& Lek S. (1995) Effects of reduced flow on brown trout (Salmo trutta) populations downstream of dams in the French Pyrenees. Regulated Rivers-Research and Management 10, 347-361.

Becker J.A., Speare D.J. \& Dohoo I.R. (2003) Effect of water temperature and flow rate on the transmission of microsporidial gill disease caused by Loma salmonae in rainbow trout Oncorhynchus mykiss. Fish Pathology 38, $105-112$.

Berland G., Nickelsen T., Heggenes J., Økland F., Thorstad E.B. \& Halleraker J. (2004) Movements of wild Atlantic salmon parr in relation to peaking flows below a hydropower station. River Research and Applications 20, 957966.

Blinn D.W., Shannon J.P., Stevens L.E. \& Carder J.P. (1995) Consequences of fluctuating discharge for lotic communities. Journal of the North American Benthological Society 14, 233-248.

Bradford M.J. \& Heinonen J.S. (2008) Low Flows, instream flow needs and fish ecology in small streams. Canadian Water Resources Journal 33, 165-180.

Budy P., Thiede G.P., Bouwes N., Petrosky C.E. \& Schaller H. (2002) Evidence linking delayed mortality of Snake River salmon to their earlier hydrosystem experience. North American Journal of Fisheries Management 22, 35 51
Bunt C.M., Cooke S.J., Katopodis C. \& McKinley R.S. (1999) Movement and summer habitat of brown trout (Salmo trutta) below a pulsed discharge hydroelectric generating station. Regulated Rivers-Research and Management 15, 395-403.

Cada G.F., Deacon M.D., Mitz S.V. \& Bevelhimer M.S. (1997) Effects of water velocity on the survival of downstream-migrating juvenile salmon and steelhead: a review with emphasis on the Columbia river basin. Reviews in Fisheries Science 5, 131-183.

Connor W.P., Burge H.L., Yearsley J.R. \& Bjornn T.C. (2003) Influence of flow and temperature on survival of wild subyearling fall chinook salmon in the Snake River. North American Journal of Fisheries Management 23, 362 375.

Crisp D.T. (1988) Prediction, from temperature, of eyeing, hatching and 'swim-up' times for salmonid embryos. Freshwater Biology 19, 41-48.

Crozier L.G. \& Zabel R.W. (2006) Climate impacts at multiple scales: evidence for differential population responses in juvenile Chinook salmon. Journal of Animal Ecology 75, 1100-1109.

Cunjak R.A. \& Therrien J. (1998) Inter-stage survival of wild juvenile Atlantic salmon, Salmo salar. Fisheries Management and Ecology 5, 209-223.

Dare M.R. \& Hubert W.A. (2002) Changes in habitat availability and habitat use and movements by two trout species in response to declining discharge in a regulated river during winter. North American Journal of Fisheries Management 22, 917-928.

Davidson R.S., Letcher B.H. \& Nislow K.H. (2010) Drivers of growth variation in juvenile Atlantic salmon: an elasticity analysis approach. Journal of Animal Ecology 79, 1113-1121.

De Staso J. \& Rahel F.J. (1994) Influence of water temperature on interactions between juvenile Colorado River cutthroat trout and brook trout in a laboratory stream. Transactions of the American Fisheries Society 123, 289-297.

Einum S. \& Nislow K.H. (2005) Local-scale density-dependent survival of mobile organisms in continuous habitats: an experimental test using Atlantic salmon. Oecologia 143, 203-210.

Einum S., Sundt-Hansen L. \& H. Nislow K. (2006) The partitioning of density-dependent dispersal, growth and survival throughout ontogeny in a highly fecund organism. Oikos 113, 489-496.

Einum S., Nislow K.H., Reynolds J.D. \& Sutherland W.J. (2008) Predicting population responses to restoration of breeding habitat in Atlantic salmon. Journal of Applied Ecology 45, 930-938.

Enders E.C., Gessel M.H. \& Williams J.G. (2009a) Development of successful fish passage structures for downstream migrants requires knowledge of their behavioural 
response to accelerating flow. Canadian Journal of Fisheries and Aquatic Sciences 66, 2109-2117.

Enders E.C., Scruton D.A. \& Clarke K.D. (2009b) The 'natural flow paradigm' and Atlantic salmon-moving from concept to practice. River Research and Applications 25, 2 15.

Fausch K.D. (1984) Profitable stream positions for salmonids: relating specific growth rate to net energy gain. Canadian Journal of Zoology 62, 441-452.

Finstad A.G., Einum S., Forseth T. \& Ugedal O. (2007) Shelter availability affects behaviour, size-dependent and mean growth of juvenile Atlantic salmon. Freshwater Biology 52, 1710-1718.

Gibbins C.N., Soulsby C., Jeffries M.J. \& Acornley R. (2001) Developing ecologically acceptable river flow regimes: a case study of Kielder reservoir and the Kielder water transfer system. Fisheries Management and Ecology 8, 463485.

Greenberg L.A. (1999) Effects of predation and discharge on habitat use by brown trout, Salmo trutta, and grayling, Thymallus thymallus, in artificial streams. Archiv Fur Hydrobiologie 145, 433-446.

Gurney W.S.C., Bacon P.J., Tyldesley G. \& Youngson A.F. (2008) Process-based modelling of decadal trends in growth, survival, and smolting of wild salmon (Salmo salar) parr in a Scottish upland stream. Canadian Journal of Fisheries and Aquatic Sciences 65, 2606-2622.

Halleraker J.H., Saltveit S.J., Harby A., Arnekleiv J.V., Fjeldstad H.P. \& Kohler B. (2003) Factors influencing stranding of wild juvenile brown trout (Salmo trutta) during rapid and frequent flow decreases in an artificial stream. River Research and Applications 19, 589-603.

Hayes J.W., Hughes N.F. \& Kelly L.H. (2007) Process-based modelling of invertebrate drift transport, net energy intake and reach carrying capacity for drift-feeding salmonids. Ecological Modelling 207, 171-188.

Hembre B., Arnekleiv J.V. \& L'Abee-Lund J.H. (2001) Effects of water discharge and temperature on the seaward migration of anadromous brown trout, Salmo trutta, smolts. Ecology of Freshwater Fish, 10, 61-64.

Henderson J.N. \& Letcher B.H. (2003) Predation on stocked Atlantic salmon (Salmo salar) fry. Canadian Journal of Fisheries and Aquatic Sciences 60, 32-42.

Huntingford F.A., Aird D., Joiner P., Thorpe K.E., Braithwaite V.A. \& Armstrong J.D. (1999) How juvenile Atlantic salmon, Salmo salar, respond to falling water levels: experiments in an artificial stream. Fisheries Management and Ecology 6, 357-364.

Huusko A., Greenberg L., Stickler M., Linnansaari T., Nykänen M., Vehanen T. et al. (2007) Life in the ice lane: the winter ecology of stream salmonids. River Research and Applications 23, 469-491.
Hvidsten N.A. (1985) Mortality of pre-smolt Atlantic salmon, Salmo salar, and brown trout, Salmo trutta, caused by fluctuating water levels in the regulated River Nidelva, central Norway. Journal of Fish Biology 27, 711-718.

Irvine R.L., Oussoren T., Baxter J.S. \& Schmidt D.C. (2009) The effects of flow reduction rates on fish stranding in British Columbia, Canada. River Research and Applications 25, 405-415.

Jager H.I. \& Rose K.A. (2003) Designing optimal flow patterns for fall Chinook salmon in a central valley, California, river. North American Journal of Fisheries Management 23, 1-21.

Jager H.I., Cardwell H.E., Sale M.J., Bevelhimer M.S., Coutant C.C. \& VanWinkle W. (1997) Modelling the linkages between flow management and salmon recruitment in rivers. Ecological Modelling 103, 171-191.

Jensen A.J. \& Johnsen B.O. (1999) The functional relationship between peak spring floods and survival and growth of juvenile Atlantic salmon (Salmo salar) and Brown trout (Salmo trutta). Functional Ecology 13, 778-785.

Jensen A.J., Johnsen B.O. \& Heggberget T.G. (1991) Initial feeding time of Atlantic salmon alevins compared to river flow and water temperature in Norwegian streams. Environmental Biology of Fishes 30, 379-385.

Johnson G.E. \& Dauble D.D. (2006) Surface flow outlets to protect juvenile salmonids passing through hydropower dams. Reviews in Fisheries Science 14, 213-244.

Jonsson B. \& Jonsson N. (2009) A review of the likely effects of climate change on anadromous Atlantic salmon Salmo salar and brown trout Salmo trutta, with particular reference to water temperature and flow. Journal of Fish Biology 75, 2381-2447.

Jonsson N., Jonsson B. \& Hansen L.P. (1998) The relative role of density-dependent and density-independent survival in the life cycle of Atlantic salmon Salmo salar. Journal of Animal Ecology 67, 751-762.

Katopodis C. (2005) Developing a toolkit for fish passage, ecological flow management and fish habitat works. Journal of Hydraulic Research 43, 451-467.

Kennedy B.P., Nislow K.H. \& Folt C.L. (2008) Habitatmediated foraging limitation drives recruitment bottlenecks for juvenile salmon. Ecology 89, 2529-2541.

Kemp P.S., Gilvear D.J. \& Armstrong J.D. (2006) Variation in performance reveals discharge-related energy costs for foraging Atlantic salmon (Salmo salar) parr. Ecology of Freshwater Fish 15, 565-571.

Korman J. \& Campana S.E. (2009) Effects of hydropeaking on nearshore habitat use and growth of age- 0 rainbow trout in a large regulated river. Transactions of the American Fisheries Society 138, 76-87.

Kukulka T. \& Jay D.A. (2003) Impacts of Columbia River discharge on salmonid habitat: 2 . Changes in shallow- 
water habitat. Journal of Geophysical Research-Oceans 108, 17.

Leániz C.G.D., Fraser N. \& Huntingford F.A. (2000) Variability in performance in wild Atlantic salmon, Salmo salar, fry from a single redd. Fisheries Management and Ecology 7, 489-502.

Letcher B.H. \& Terrick T.D. (1998) Maturation of male age-0 Atlantic salmon following a massive, localized flood. Journal of Fish Biology 53, 1243-1252.

Letcher B.H., Dubreuil T., O’Donnell M.J., Obedzinski M., Giswold K. \& Nislow K.H. (2004) Long-term consequences of variation in timing and manner of fry introduction on juvenile Atlantic salmon (Salmo salar) growth, survival, and life-history expression. Canadian Journal of Fisheries and Aquatic Sciences 61, 2288-2301.

Liebig H., Lim P. \& Belaud A. (1998) Influence of basic flow and hydropeaking duration on the drift of post-emergent fry of brown trout: experiments on a semi-natural stream. Bulletin Francais de la Peche et de la Pisciculture 350, 337 347.

Lobon-Cervia J. (1996) Response of a stream fish assemblage to a severe spate in northern Spain. Transactions of the American Fisheries Society 125, 913-919.

Lobon-Cervia J. (2004) Discharge-dependent covariation patterns in the population dynamics of brown trout (Salmo trutta) within a Cantabrian river drainage. Canadian Journal of Fisheries and Aquatic Sciences 61, 1929-1939.

Marshall E. \& Randhir T. (2008) Effect of climate change on watershed system: a regional analysis. Climatic Change 89, 263-280.

McCormick S.D., Saunders R.L., Hansen L.P. \& Quinn T.P. (1998) Movement, migration, and smolting in Atlantic salmon (Salmo salar). Canadian Journal of Fisheries and Aquatic Sciences 55(Suppl.1), 77-92.

McCormick S.D., Cunjak R.A., Dempson B., O’Dea M.F. \& Carey J. (1999) Temperature-related loss of smolt characteristics in Atlantic salmon in the wild. Canadian Journal of Fisheries and Aquatic Sciences 56, 1648-1649.

McKinney T., Speas D.W., Rogers R.S. \& Persons W.R. (2001) Rainbow trout in a regulated river below Glen Canyon Dam, Arizona, following increased minimum flows and reduced discharge variability. North American Journal of Fisheries Management 21, 216-222.

Murchie K.J., Hair K.P.E., Pullen C.E., Redpath T.D., Stephens H.R. \& Cooke S.J. (2008) Fish response to modified flow regimes in regulated rivers: research methods, effects and opportunities. River Research and Applications 24, 197-217.

Nislow K.H. \& Lowe W.H. (2006) Influences of logging history and riparian forest characteristics on macroinvertebrates and brook trout (Salvelinus fontinalis) in head- water streams (New Hampshire, U.S.A.). Freshwater Biology 51, 388-397.

Nislow K.H., Folt C.L. \& Parrish D.L. (2000) Spatially explicit bioenergetic analysis of habitat quality for age- 0 Atlantic salmon. Transactions of the American Fisheries Society 129, 1067-1081.

Nislow K.H., Magilligan F.J., Folt C.L. \& Kennedy B.P. (2002) Within-basin variation in the short-term effects of a major flood on stream fishes and invertebrates. Journal of Freshwater Ecology 17, 305-318.

Nislow K.H., Sepulveda A.J. \& Folt C.L. (2004) Mechanistic linkage of hydrologic regime to summer growth of age- 0 Atlantic salmon. Transactions of the American Fisheries Society 133, 79-88.

Orpwood J.E., Griffiths S.W. \& Armstrong J.D. (2006) Effects of food availability on temporal activity patterns and growth of Atlantic salmon. Journal of Animal Ecology 75, 677-685.

Poff N.L., Allan J.D., Bain M.B., Karr J.R., Prestegaard K.L., Richter B.D. et al. (1997) The natural flow regime. BioScience 47, 769-784.

Reese C.D. \& Harvey B.C. (2002) Temperature-dependent interactions between juvenile steelhead and Sacramento pikeminnow in laboratory streams. Transactions of the American Fisheries Society 131, 599-606.

Rieman B.E., Beamesderfer R.C., Vigg S. \& Poe T.P. (1991) Estimated loss of juvenile salmonids to predation by northern squawfish, walleyes, and smallmouth bass in John Day Reservoir, Columbia River. Transactions of the American Fisheries Society 120, 448-458.

Riley W.D., Maxwell D.L., Pawson M.G. \& Ives M.J. (2009) The effects of low summer flow on wild salmon (Salmo salar), trout (Salmo trutta) and grayling (Thymallus thymallus) in a small stream. Freshwater Biology 54, 25812599.

Salant N.L., Renshaw C.E., Magilligan F.J., Kaste J.M., Nislow K.H. \& Heimsath A.M. (2007) The use of shortlived radionuclides to quantify transitional bed material transport in a regulated river. Earth Surface Processes and Landforms 32, 509-524.

Smith B.D. (2000) Trends in wild adult steelhead (Oncorhynchus mykiss) abundance for snowmelt-driven watersheds of British Columbia in relation to freshwater discharge. Canadian Journal of Fisheries and Aquatic Sciences 57, 285-297.

Solomon D.J. \& Paterson D. (1980) Influence of natural and regulated streamflow on survival of brown trout (Salmo trutta) in a chalkstream. Environmental Biology of Fishes $\mathbf{5}$, 379-382.

Sommer T.R., Harrell W.C., Solger A.M., Tom B. \& Kimmerer W. (2004) Effects of flow variation on channel and floodplain biota and habitats of the Sacramento River, 
California, USA. Aquatic Conservation-Marine and Freshwater Ecosystems 14, 247-261.

Souchon Y., Sabaton C., Deibel R., Reiser D., Kershner J., Gard M. et al. (2008) Detecting biological responses to flow management: missed opportunities; Future directions. River Research and Applications 24, 506-518.

Stradmeyer L., Höjesjö J., Armstrong J. \& Griffiths S. (2003) Behavioural strategies for species co-existence during environmental extremes: competition between trout and salmon parr during dewatering. Journal of Fish Biology 63, $242-242$.

Stradmeyer L., Höjesjö J., Griffiths S.W., Gilvear D.J. \& Armstrong J.D. (2008) Competition between brown trout and Atlantic salmon parr over pool refuges during rapid dewatering. Journal of Fish Biology 72, 848-860.

Tetzlaff D., Soulsby C., Youngson A.F., Gibbins C., Bacon P.J., Malcolm I.A. et al. (2005) Variability in stream discharge and temperature: a preliminary assessment of the implications for juvenile and spawning Atlantic salmon. Hydrology and Earth System Sciences 9, 193-208.
Troelstrup N.H. \& Hergenrader G.L. (1990) Effect of hydropower peaking flow fluctuations on community structure and feeding guilds of invertebrates colonizing artificial substrates in a large impounded river. Hydrobiologia 199, 217-228.

Walsh C.L. \& Kilsby C.G. (2007) Implications of climate change on flow regime affecting Atlantic salmon. Hydrology and Earth System Sciences 11, 1125-1141.

Ward D.M., Nislow K.H. \& Folt C.L. (2009) Increased population density and suppressed prey biomass: relative impacts on juvenile Atlantic salmon growth. Transactions of the American Fisheries Society 138, 135-143.

Xu C.L., Letcher B.H. \& Nislow K.H. (2010a) Context-specific influence of water temperature on brook trout growth rates in the field. Freshwater Biology 55, 2253-2264.

Xu C.L., Letcher B.H. \& Nislow K.H. (2010b) Size-dependent survival of brook trout Salvelinus fontinalis in summer: effects of water temperature and stream flow. Journal of Fish Biology 76, 2342-2369. 